\title{
Facies Analysis, Depositional Environment and Diagenetic Features of the Qom Formation in the Saran Semnan, Central Iran
}

\author{
Fereshteh Karami-Movahed ${ }^{1}$, Mohsen Aleali2 ${ }^{*}$, Parviz Ghazanfari ${ }^{3}$ \\ ${ }^{1}$ Faculty of Basic Sciences, Department of Geology, Islamic Azad University, North Tehran Branch, Tehran, Iran \\ ${ }^{2}$ Department of Geology, Science and Research Branch, Islamic Azad University, Tehran, Iran \\ ${ }^{3}$ Department of Geology, Imam Khomeini International University of Science, Qazvin, Iran \\ Email: *m.aleali@srbiau.ac.ir
}

Received 6 February 2016; accepted 14 June 2016; published 17 June 2016

Copyright (C) 2016 by authors and Scientific Research Publishing Inc.

This work is licensed under the Creative Commons Attribution International License (CC BY). http://creativecommons.org/licenses/by/4.0/

c) (i) Open Access

\begin{abstract}
In this study, to identify and analyze facies of depositional environment and depositional model of Qom Formation, stratigraphic Saran Section (southwest of Semnan) was selected. Qom Formation in Saran section includes about 380 meters of conglomerate at the base, chalk, limestone, marl, and shale. Petrographic studies with facies analysis have led to the identification of 12 microfacies, these microfacies have been deposited in four facies groups including tidal flat, lagoon, barrier and open marine. Study of horizontal and vertical facies changes and their comparison with recent and ancient environments reveals that Qom Formation in this section relates to shallow marine environment and its facies were deposited in a shelf carbonate platform and are comparable with contemporary shelf platforms such as Florida and old shelf platforms such as Mozduran. The most important diagenetic processes affecting the studied section include micritization, bioturbation, cementation, dissolution, neomorphism, fracturing, mechanical and chemical compaction, hematitization and dolomitization. These processes have formed in marine, meteoric and burial diagenetic environments.
\end{abstract}

\section{Keywords}

Facies Analysis, Depositional Environment, Qom Formation, Saran Semnan, Centeral Iran

\section{Introduction}

Qom Formation (Oligo-miocene) is composed of clastic and carbonate sediments. This formation with great

*Corresponding author.

How to cite this paper: Karami-Movahed, F., Aleali, M. and Ghazanfari, P. (2016) Facies Analysis, Depositional Environment and Diagenetic Features of the Qom Formation in the Saran Semnan, Central Iran. Open Journal of Geology, 6, 349-362. http://dx.doi.org/10.4236/ojg.2016.66030 
extension is one of the formations of central Iran zone that after the discovery of hydrocarbon reserves in 1934, it has received great importance and has been of interest for many geologists (Figure 1(a)). In general, following the Pyrenean event and a continental sedimentation in the lower Oligocene, a beam of west central Iran to the south Jazmurian shuttle has been covered with a progressive sea. The advance and retreat of the sea is not the same everywhere [1]. In general, Sedimentation of Qom Formation in two progressive fronts has started from Oligocene and continued to Lower Miocene [2].

Since facies changes of Qom Formation is high, section pattern has not been introduced for it so far, but considering the abundance of outcrops of this formation in Qom area, this area has been considered as a model area for it. Qom Formation has been studied in the various regions of Iran, which contains valuable points, but few studies have been in Semnan area.

In this study, Saran stratigraphic section was studied (Figure 1(b)). Although many studies have been done

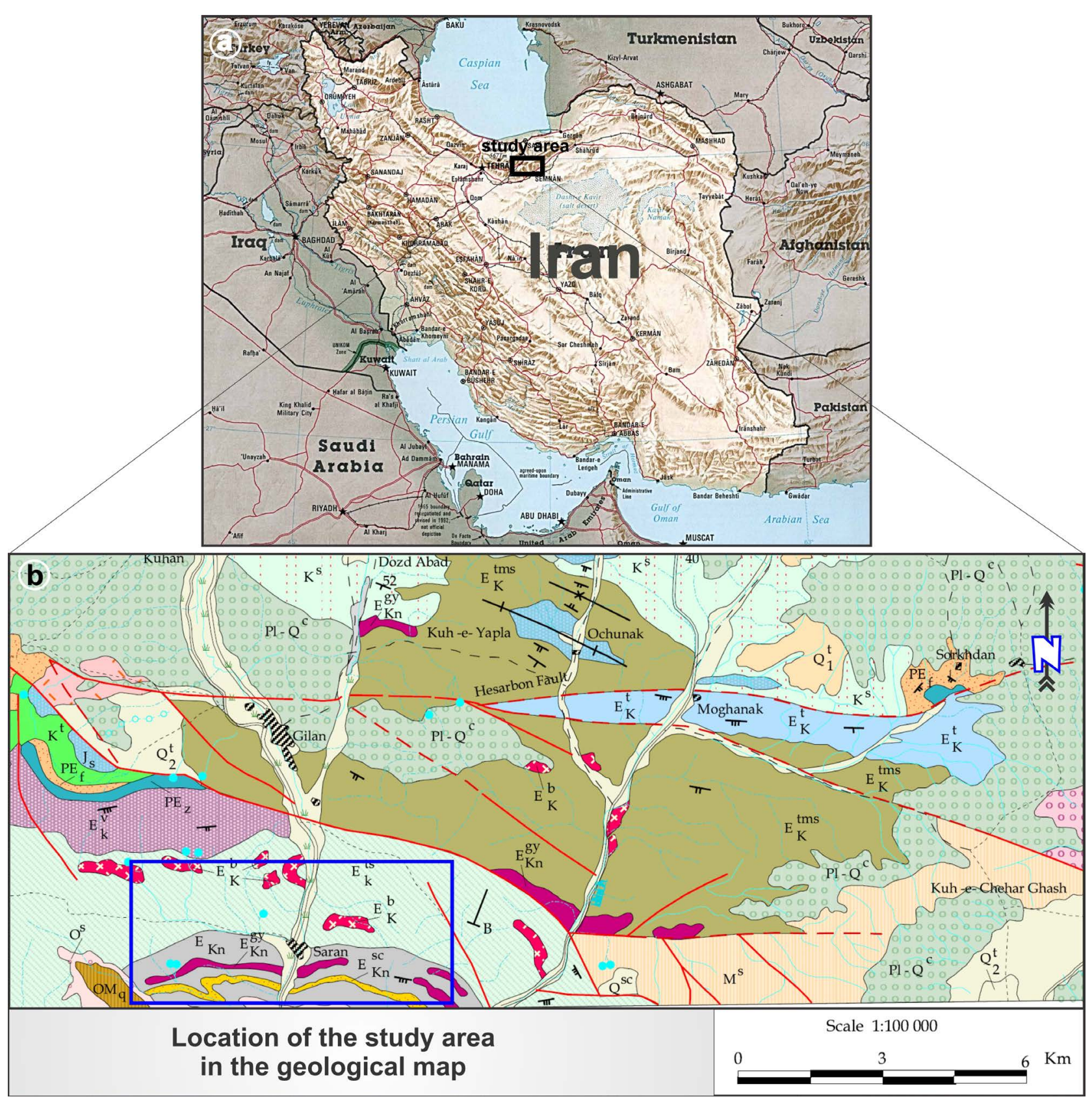

Figure 1. (a) Location of the study area of the Iran map; (b) Geological map of the study area (Saran Semnan). 
on Qom Formation, it is still incomplete in many cases, among which is little research in Semnan area about Qom Formation sedimentary facies and environments.

Therefore, the following points were considered as the study objectives in stratigraphic section:

1) Studying lithostratigraphy of Qom Formation in Saran Semnan section and drawing the stratigraphic column; 2) Examining microfacies of Qom Formation in Saran Semnan section; 3) Interpreting depositional environment and suggesting depositional environment change curves; 4) determining diagenetic of Qom Formation; and 5) Suggesting the sedimentary model.

Until now, many researchers have been studied Facies Analysis, Depositional Environment (e.g. [3]-[9]).

\subsection{Lithostratigraphy}

Qom Formation in Saran section on a map scale of 1:100,000 Semnan (Figure 1(b)) is mainly composed of limestone, clay and marl, conglomerate, sandstone, marl gray and dark red, bright red sandstone and evaporating rocks (Figure 2 and Figure 3(a)). Outcrops of Qom Formation is in south of Semnan with thickness of more

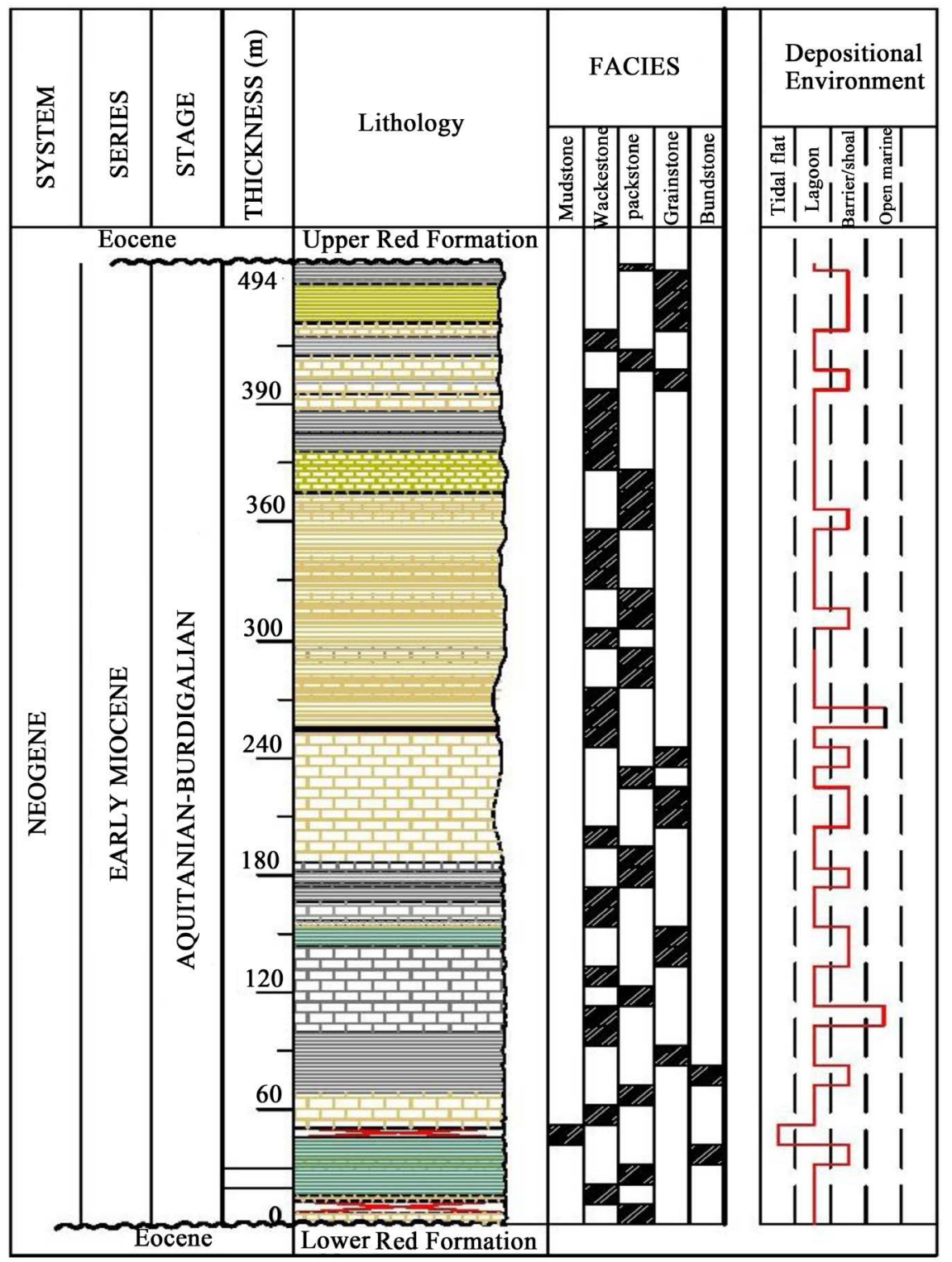

Figure 2. Lithostratigraphic column, Vertical facies and depositional distribution of the Qom Formation at Saran section. 


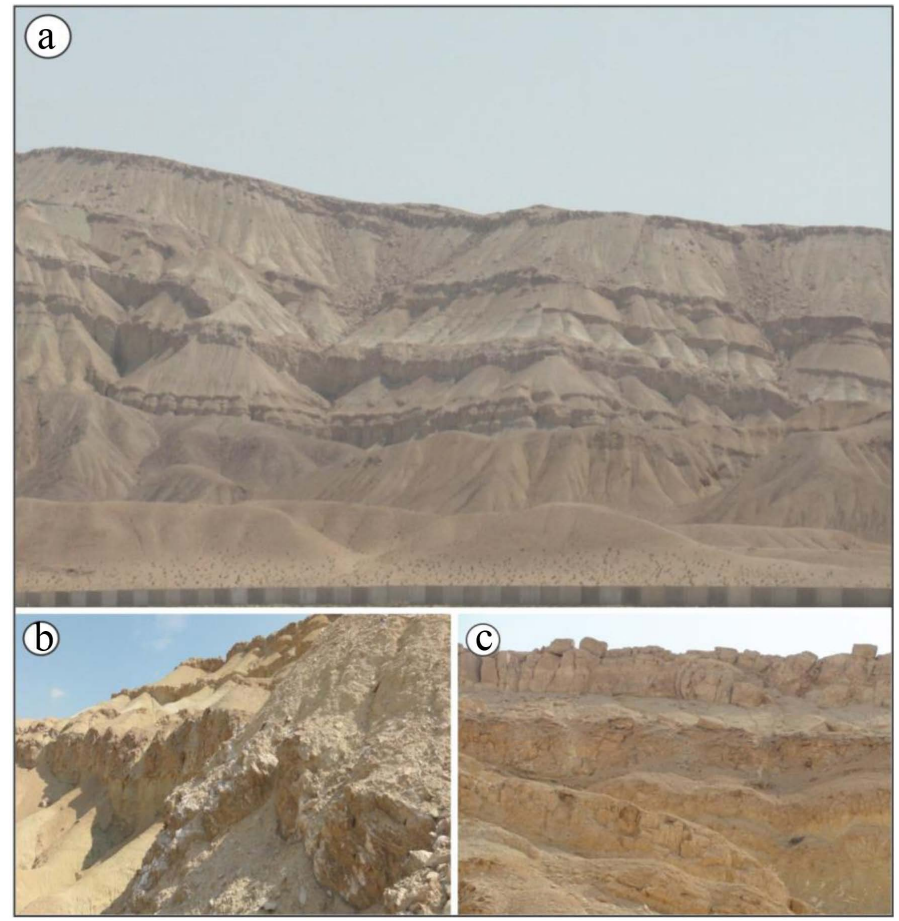

Figure 3. (a) General view of the study section (Saran Semnan). (b) limestone and gypsum layers in the middle part of Qom Formation. (c) Thick bedded to massive limestones in upper part of Saran section.

than 300 meters of fossils limestone with gypsum marl interlayers (Figure 2, Figure 3(b) and Figure 3(c)). The lower boundary of this formation has discontinuities red shale with red formation conformably below the upper border of it as the disconformity with URF is red shale.

Moreover, most parts of the URF and the top of Qom Formation is lost due to erosion. With regard to the species of benthic foraminifera, the age of Burdigalian (equivalent to member $\mathrm{f}$ in the central part of the basin) has been determined for the sediments. In the southern area of Jaamin-Gerdab anticline (in southern Gerdabrail way station), Qom Formation is formed of limestone, marl and marl, gypsum bearing sand. The greatest thickness of Qom Formation in the area is in northern flank of spa anticline, as 420 meters. It seems that from this part towards the north the amount of damaging material increases. In east of Haji Abad Anticline, limestone facies of Qom Formation are completely replaced by sandstone, red marl and gypsum [2].

\subsection{Geological Setting}

Berberian (1981) considers the reason of Formation of the sedimentary basin of Qom in central Iran due to existence of active continental margin in southwestern Iran in Oligo-miocene age. According to him, the subduction has created the backarc opening in the center and north central Iran and the marine sediments of the Qom Formation is made up with alkaline magmatic activity. The opening occurred coincided with the push button of tectonic regime that was imposed on Iran (ZHU et al., 2007). Most studies on the age of Qom Formation state its age from middle Oligocene to Lower [10]-[14].

\subsection{Materials and Methods}

The present paper is based on field and laboratory examination of the Qom Formation from the Saran Semnan section. Two outcrop sections were collected and more than 300 samples and thin sections examined to assign sedimentological characteristics, facies types, and depositional model. Whole of thin sections were half-stained with Alizarin Red-S to denotation calcite from dolomite. Carbonate facies analysis is carried out based on Dunham (1962) [15] carbonate classification models. For determine depositional environments concepts of standard 
depositional environment models and distribution of facies was used (e.g. Wilson, 1975; Reading, 1996; Tucker, 2001; Pomar, 2001; Flugel, 2010) [16]-[20]. For recognize diagenetic features and processes fundamental diagenetic definitions were applied.

\section{Carbonate Components}

According to Folk (1980) [21] components of carbonate rocks can be placed in two groups: orthochems and allochems. Allochems are divided to two main categories of skeletal and non-skeletal carbonate particles [20]. The most important skeletal carbonate particles of the Qom Formation are benthic foraminifera, planktonic foraminifera, red algae, echinoderms, corals, bryozoan, sponge spicules, bivalves, gastropods, brachiopods and ostracods and the main non-skeletal carbonate is peloid (Figures 4(a)-(I)). Micrite, microsparite and sparry calcite are the major types of orthochem in the study area. In addition, the most important Non-Carbonate Components include quartz, feldspar, rock fragments, glauconite and phosphate (Figures 5(a)-(f)).

\subsection{Diagenetic Features}

Based on sedimentary-petrographic analysis of the Qom Formation several diagenetic features are identified in the studied thin section include micritization, bioturbation, cementation, dissolution, neomorphism, fracturing, mechanical and chemical compaction, hematitization and dolomitization which are discussed separately. These features are formed to three major diagenetic settings including shallow water marine, meteoric, and burial diagenetic environments.

\subsubsection{Micritization}

Micritization is a process by which grains in a carbonate sediment (allochems) are transformed into fine-grained calcite from their original form usually removing their internal structure. Micritization occurs due to the action of endolithic algae (non-skeletal blue green algae) which bore into bioclasts [22] [23]. In the study thin sections, around of most of lagoon grains micritic envelope (dark color cover) is observed (Figure 6(a)).
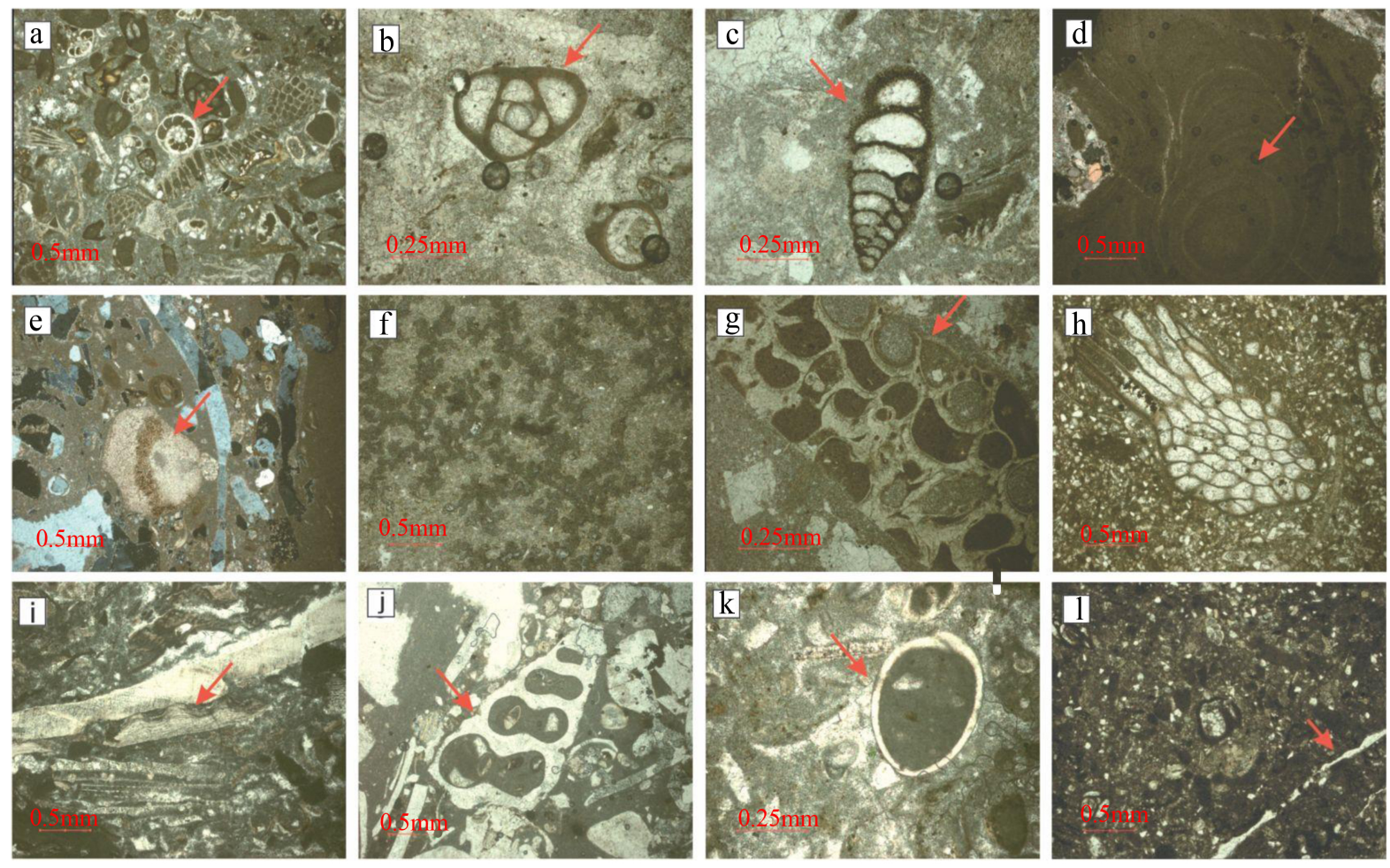

Figure 4. Photomicrographs of the main carbonate components of Qom Formation. (a), (b) and (c) Benthic foraminifera, (d) red algea, (e) echinoderm, (f) coral, (g) and (h) bryozoan, (i) bivalve debris (j) gastropoda, (k) ostracods, (l) peloid grains. 

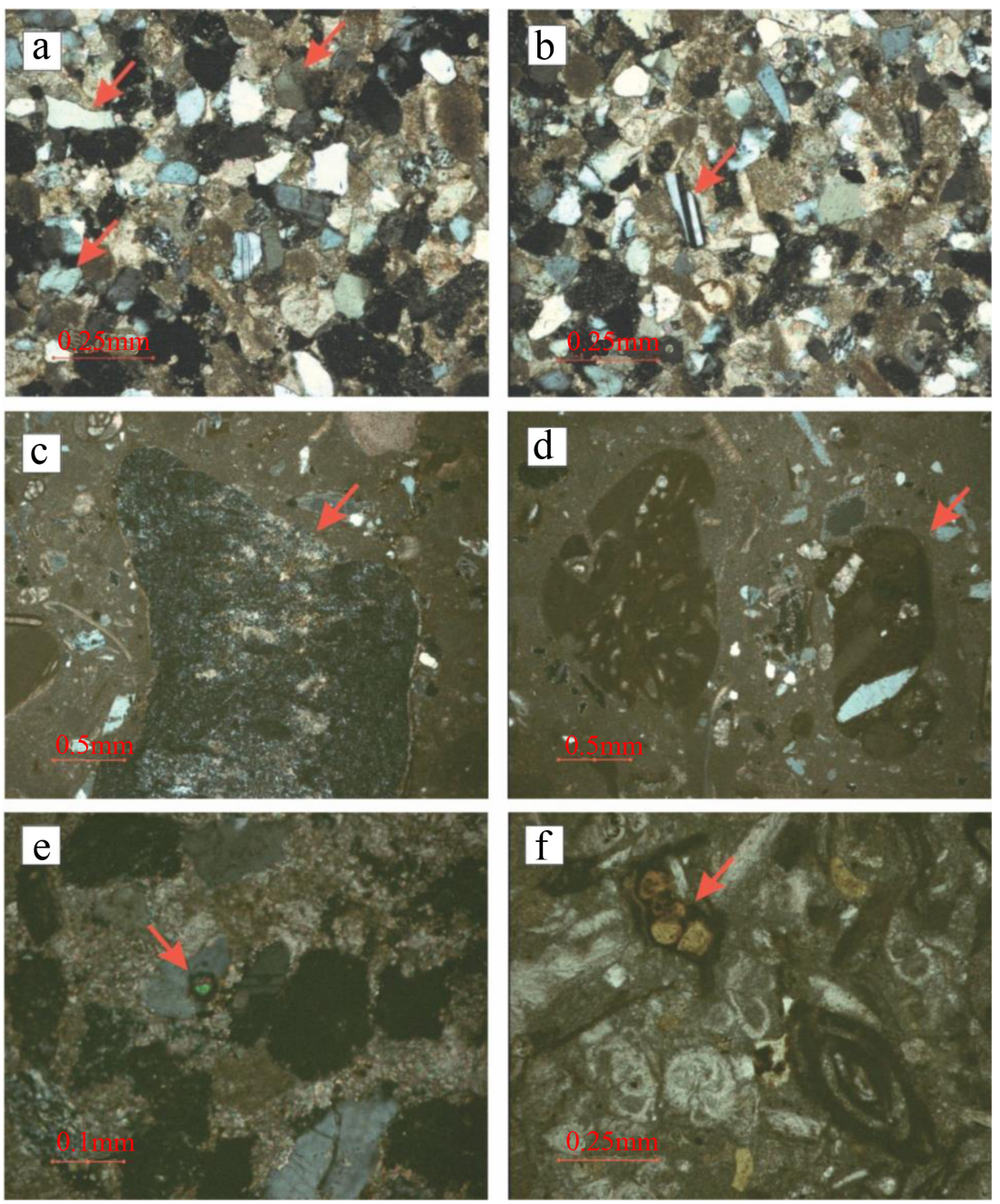

Figure 5. Photomicrographs of the main non-carbonate components of Qom Formation. (a) quartz, (b) feledspar, (c) volcanic rock fragment, (d) sedimentary rock fragment, (e) glauconite, (f) phosphate.

\subsubsection{Bioturbation}

Bioturbation is the most common forms of biogenetic diagenesis features in shallow and deep marine environment [20]. In the studied section, this phenomenon was observed in shallow water carbonate. Boring and burrow are the main bioturbation types in Qom Formation (Figure 6(b)). In the studied section, boring has occurred only the fossil fragments and these holes are then filled by calcite.

\subsubsection{Cementation}

Studies on the Qom Formation in the study area showed that calcite cement is the most common type of cement in this Formation. This type of cement has filled many empty spaces within or/and between grains, pellets, porous and fracture in the Formation. According to the diagenetic, calcite cement was observed in different ways including Equantcalite Cement, Granular Cement, Blocky Cement and Drusy Calcite Cement (Figure 6(c) \& Figure 6(d)).

\subsubsection{Dissolution}

Dissolution of carbonate is a process that may happen in different diagenetic environment, specially meteoric environment, water mixing zone and also the burial (Tucker, 2001). Dissolution in the Qom Formation created different types of porosity including moldic and vuggy porosity. 

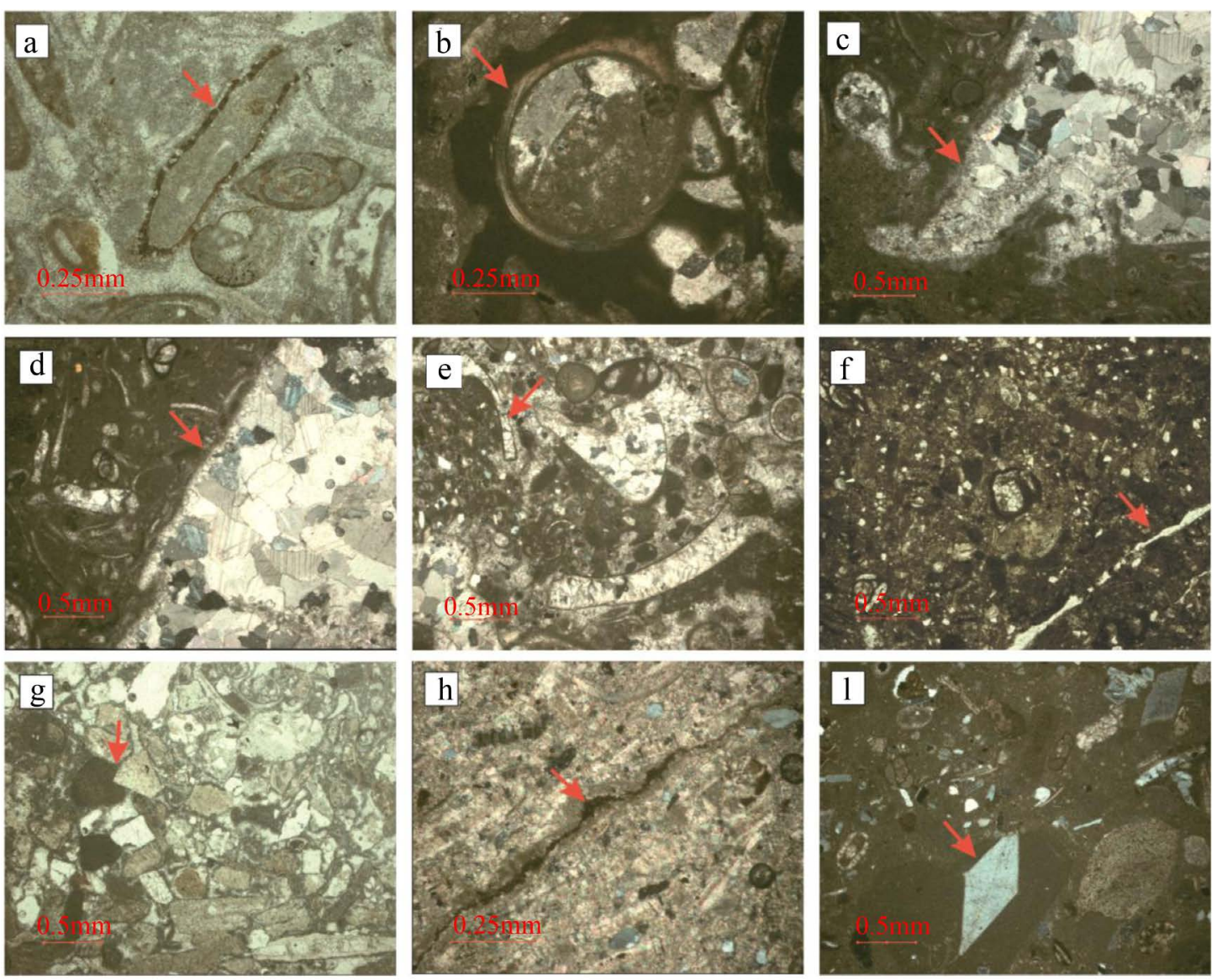

Figure 6. Photomicrographs of the main diagenetic features of Qom Formation. (a) micritization, (b) bioturbation,

(c) and (d) cementation, (e) Neomorphism, (f) fracture, (g) micritization, (b) bioturbation, (c) and (d) cementation,

(g) mechanical compaction, (g) chemical compaction (stylolite), (i) dolomitization.

\subsubsection{Neomorphism}

Neomorphism process in the studied section is of increasing type and often seen in facies related to shallow environment (Figure 6(e)).

\subsubsection{Fracturing}

In the studied sections, often first-generation fractures were identified: the first generation that occurred in shallow burial (Figure 6(f)).

\subsubsection{Compaction}

Petrographic studies of Qom Formation indicate that in the studied section, the compaction in this Formation has happened both in mechanical and chemical ways (Figure 6(g) \& Figure 6(h)). Mechanical compaction process in the Formation has been in form of reducing intergranular space, rearrangement of grain and crushing and breaking of grains. Chemical compaction caused by increased pressure causing the dissolution of the grain boundary and gradually stylolite. Due to changes in the texture and density as a result of original rock, a lot of intergranualr empty spaces of Qom Formation are destroyed and margins of stylolite zones, iron oxide cement has occupied a lot of space. Thus, physical compaction is seen as one of the most important diagenetic phenomena reducing porosity in the studied section.

\subsubsection{Hematitization}

In the studied section, the hematitization process occurs mainly along stylolite and colonization area, as well as fillingfossil cells and dissolution cavities. 


\subsubsection{Dolomitization}

Dolomitizationis not very prevalent in carbonate sediments of the Qom Formation and these Dolomite crystals are sporadically seen in the deposits (Figure 6(i)).

\subsection{Paragenetic Sequence of Qom Formation in Saran Section}

Studying diagenetic phenomena in Qom Formation section shows that these phenomena are not linear and one-sided processes, but processes are diverse and affect the deposit to large depth of burial and uplift even after repeatedly affecting the existing deposits and of each other may affect the intensity and the performance of other processes. So in addition to knowledge of these processes, identifying sequence or precedence is also an important issue (Figure 7).

Qom Formation deposition at the same time or shortly after their deposition, creatures activity has caused perturbations in the sediments with localized variations in color and texture that work like deposits that can be detected. Primary porosity and fabric are formed at this stage. Coincided with the diagenetic phenomena above in the phreatic marine environment to shallow burial depth, compaction as a continuous diagenetic phenomenon affects deposits and leads to more reduction of intergranular space. Diagenetic processes in meteoric environment continue. Deposits that were buried in shallow depth affected by diagenesis in phreatic marine environment, at this stage and as influence by meteoric and saturated waters connected to calcium carbonate, a part of their skeletal components with unstable mineralogical composition (aragonite and calcite with high magnesium) is resolved. Thus, the most important diagenetic phenomenon in this environment is dissolution and formation of secondary porosity. It seems that a part of the cement of calcite, blocky, drusy and dog-tooth cement type has occupied the empty spaces between the grains of diagenetic environment and the grains. At the continuation of the compaction process, while reducing the intergranular spaces more, carbonate allochemsget closer together and some of them are broken.

Dolomitization, the emergence of chemical compaction, such as convex-concave boundaries of the grains, veinlets and eventual dissolution stylolite in Qom Formation is indicative diagenesis environment of burial area. Fractures that cut all the constituent elements of rock, including grains, matrix, cement and forms dense diagenetic

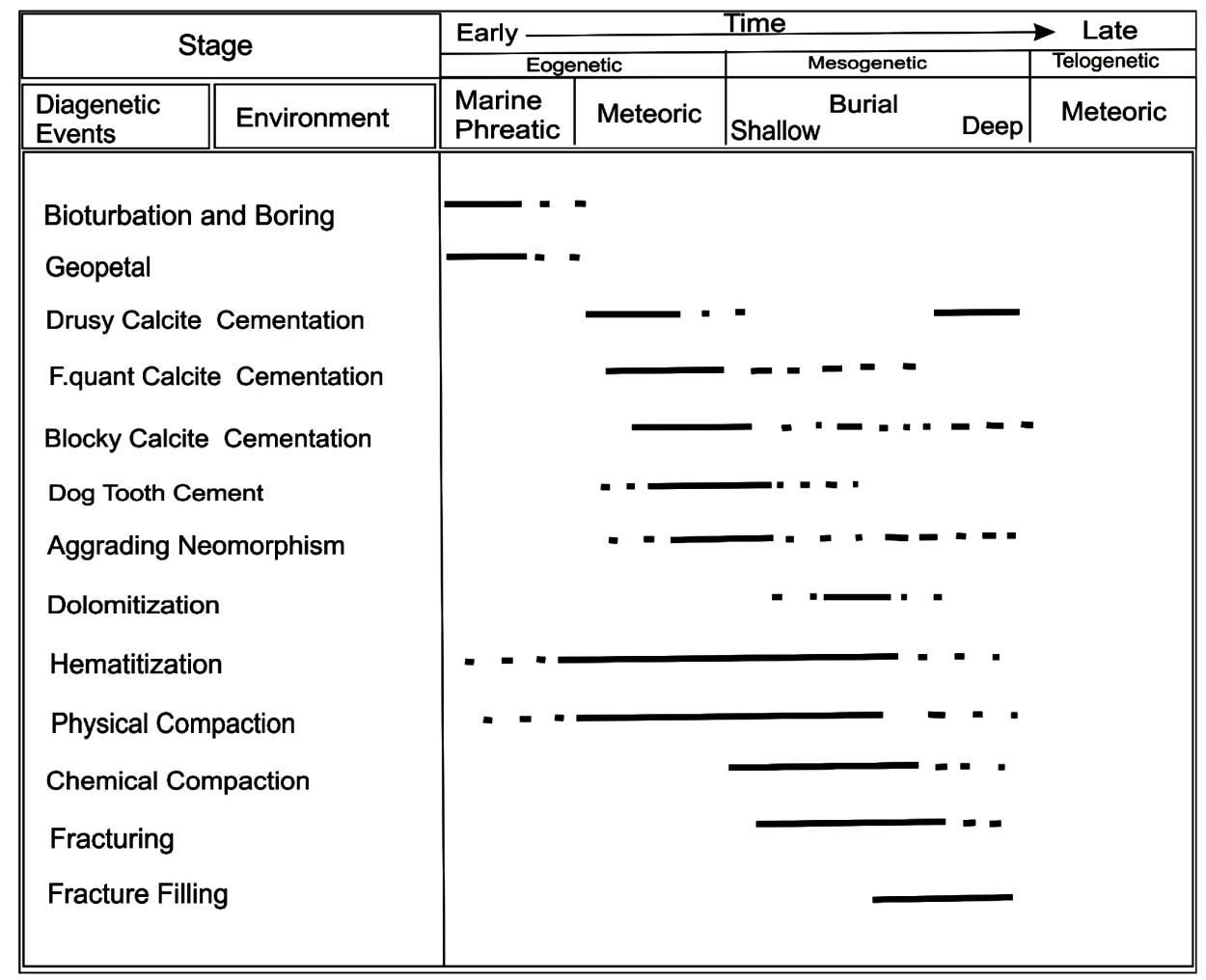

Figure 7. Paragenetic sequence of Qom formation in saran section. 
such as seeds and stylolite intersect and also cement sparry calcite fracture fillings are among the last phenomena of deep burial diagenetic environment. Deposits are exposed to surface diagenetic (atmospheric) processes again due to erosion or tectonic uplift [24]. Dissolution by meteoric waters and karstification are of the diagenetic products occurring on these deposits during this stage. In Figure 7, the paragenesis sequence of diagenetic events of Qom Formation in Saran section and their relationship with time and depth of burial are provided.

\section{Microfacies Description and Interpretation}

Based on petrographic and sedimentology analysis of the Qom Formation 12 microfacies types can be identified into four facies groups. These comprise the tidal flat (A), lagoon (B), barrier (C) and open marine (D) facies group.

\subsection{Tidal Flat Facies Group (A)}

\section{A1) Fenestral mudstone}

This faciesis composed of marl and mudstone where less than $10 \%$ of the fossils and fossil particular has not seen in it yet. The most important fabric of this fine-grained facies is bird's eye (fenestral) fabric. In some instances of this facies, silt-sized destructive quartz is also visible (Figure 8(a)). This context in this Microfacies
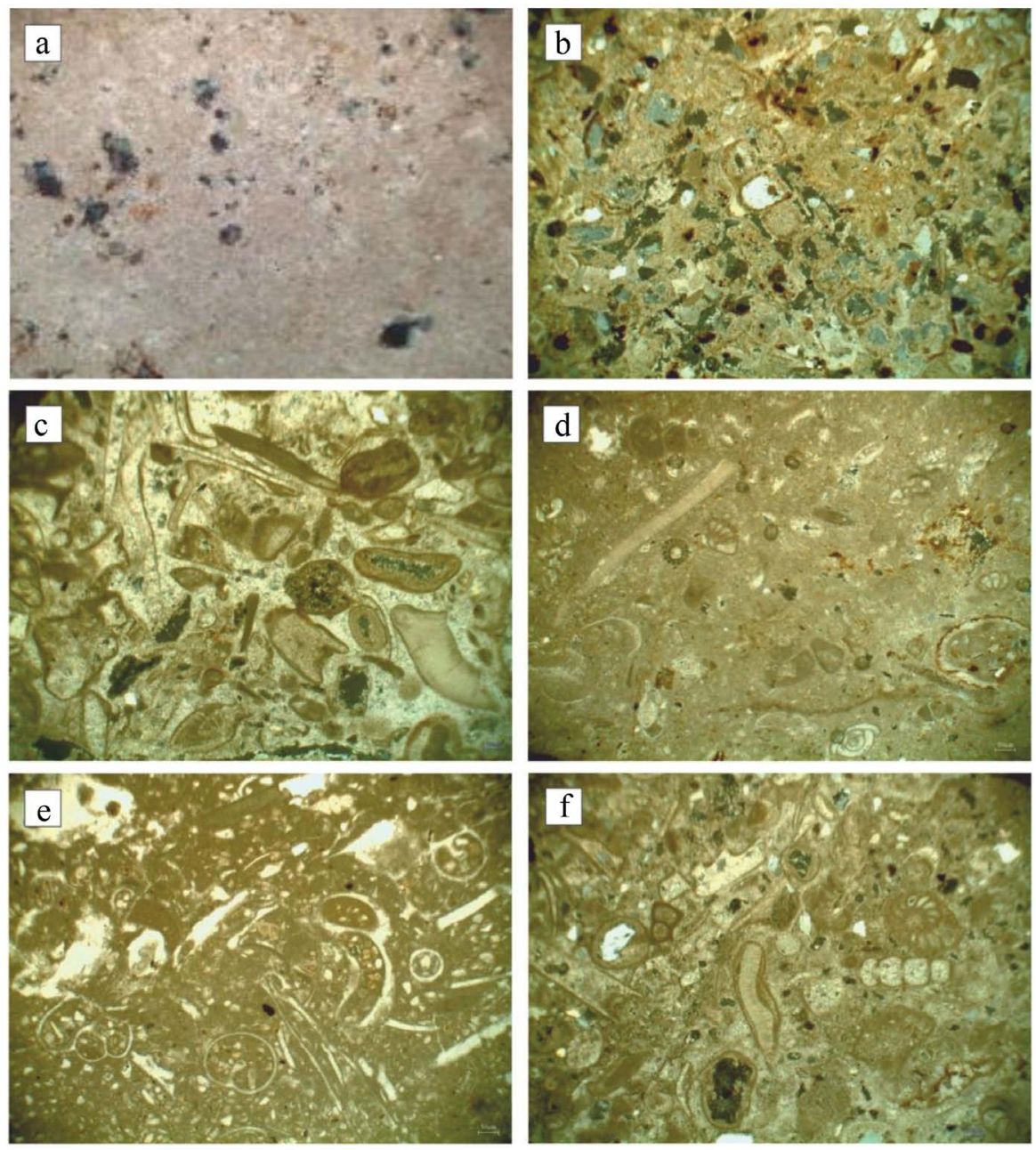

Figure 8. Photomicrographs of the tidal flat and lagoon facies types of Qom Formation. (a)

Fenestral mudstone, (b) Sandy bioclast wackestone/packstone, (c) Gastropoda ostracods bioclast grainstone, (d) Benthic foraminifera bioclast wackestone, (e) Sandy gastropod bioclast wackestone/packstone, (f) Bioclast packstone with bioturbation. 
is madeup of microcrystalline clay. Low percentage of grains in this facies shows calm and turbulence free waves conditions. Due to bird's eye fabrics in this microfacies are created because of trapped bubbles of foam waves coast and fermentation of organic matter algae and photosynthesis in deposits, because of the absence and the existence of bird's eye fabric of this facies is the closest facies to the land. These microfacies represent the tidal and inter-tidal environment and super-tidal index. This facies matches facies (24) described by Flugel (2010) [20] and facies No. 8 described by Wilson (1975) [16].

\section{A2) Sandy bioclast wackestone/packstone}

This facies characterized by bryozoan, miliolids and red algae fossils, peloids grains along with abundant detrital grains. Terrigenous grains include quartz, feldspar with coarse silt to medium sand size. Carbonate cement fills the spaces between the grains (Figure 8(b)). Looking at the position of stratigraphy and existence of micro benthic fossils in this facies, tidal flat environment is identified for it. Detrital components mainly consist of quartz, feldspar and rubbles especially in volcanic rocks from coarse silt to medium sand size parts that split along bryozoan and miliolids, surrounded by carbonate cement. This facies matches facies (21) described by Flugel (2010) [20] and facies (9) described by Wilson (1975) [16].

\section{A3) Gastropoda ostracods bioclast grainstone}

The main allochems of this facies are shell fragments, ostracods, gastropods and benthic foraminifera (especially miliolids). The subordinate components of this facies are small and minor peloid and intraclasts, which are located in the sparry calcite cement (Figure 8(c)). The frequency of coarse particles Gastropoda, bivalves and Ostracods that are placed together with sparry calcite cement on one hand and shortages related to the open marine creatures on the other hand indicate the Formation of this facies in the energetic sector tidal environment (Subtidal). This sub-environment formed in the tidal flat channels that origins of lagoon environment and passes from tidal flat area. This facies matches facies (18) described by Flugel (2010) [20] and facies (8) described by Wilson (1975) [16].

\subsection{Lagoon Facies Group (B)}

\section{B1) Benthic foraminifera bioclast wackestone}

This facies consists of mud-supported texture with less than $50 \%$ grains. The major allochems of this facies are benthic foraminifera (up to $10 \%$ ), bivalve (up to $10 \%$ ), and echinoderm (up to $8 \%$ ) debris, Bryozoan (up to 5\%), and peloids (around 10\%) (Figure 8(d)). Bioturbation and micritization are the main diagenetic features. The occurrence of lime mudstone, lagoon fauna and the abundance of peloids show this facies is made in the deeper lagoon environment. This facies matches with facies (10) described by Flugel (2010) [20] and facies (7) by Wilson (1975) [16].

\section{B2) Sandy gastropod bioclast wackestone/packstone}

The matrix of this microfacies is dark brown microcrystalline calcite (micrite). The main allochems are benthic Foraminifera, Gastropod, Ostracods, Echninoderm and bivalve fragments (Figure 8(e)). Also, Bioturbation and micritization are observed in this facies. The abundance of Gastropoda and benthic foraminifera that indicates environments with limited water circulation and the existence of grains of fine to medium-grained sized in this facies confirms lagoon setting behind the barrier with calm to medium energy. This facies matches facies (10) described by Flugel (2010) [20] and facies (7) by Wilson (1975) [16].

\section{B3) Bioclast packstone with bioturbation}

This facies consists of grain supported texture with more than $50 \%$ grains. This facies is characterized by bioturbated matrix. Benthic foraminifera, green alge, bivalve and echinoderm fragments, gastropod, ostracods and peloid grains are principal grains (Figure $8(\mathrm{f})$ ). Abundance of benthic lagoon fauna such as benthic foraminifera and gastropod, bioturbated matrix indicated that this facies deposits in the lagoon conditions. This facies matches facies (10) described by Flugel (2010) [20] and facies (7) by Wilson (1975) [16].

\subsection{Barrier Facies Group (C)}

\section{C1) Benthic foraminifera bioclast grainstone}

The benthic foraminifera bioclast grainstone mostly composed of skeletal grains cemented by spary calcite. The dominant allochems are benthic foraminifera, bivalve and echinoderm fragments, red algae, gastropod and peloid (Figure 9(a)). The absence of mud (or lesser mud contents) in this facies suggested high-energy barrier environment. This facies matches facies (12) described by Flugel (2010) [20] and facies (6) by Wilson (1975) [16]. 

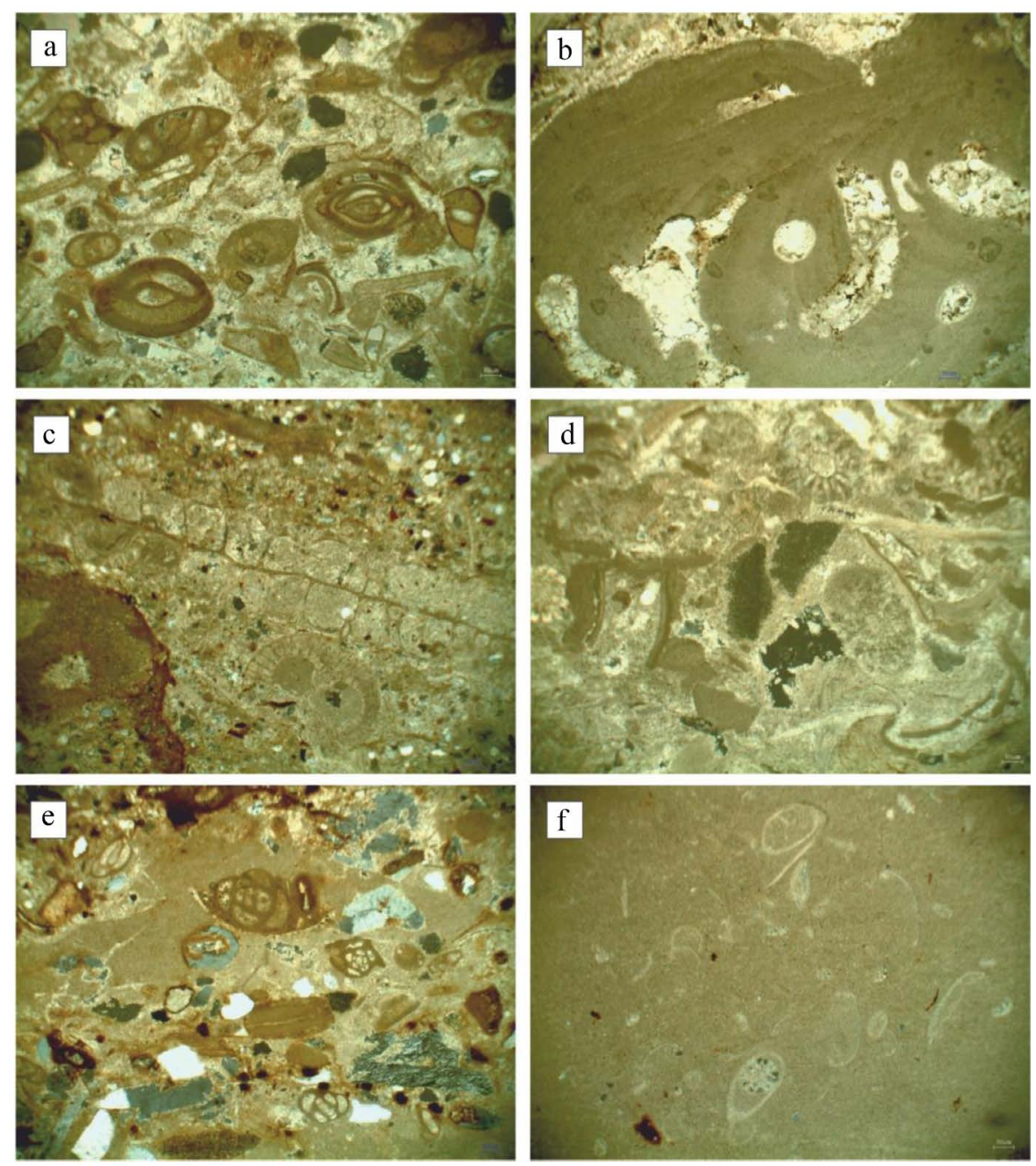

Figure 9. Photomicrographs of the barrier and open marine facies types of Qom Formation. (a) Benthic foraminifera bioclast grainstone, (b) Red Algal Boundstone, (c) Bryozoan bioclastpackstone, (d) Red Algal bioclast packestone/Grainstone, (e) claciturbidite, (f) ostoracode wackestone.

C2) Red Algal Boundstone

This facies is characterized by colonial, in situ and unbroken red algae and has been recognized in the barrier sub environments (Figure 9(b)). The occurrence of in-situ organisms such as colonial corals and red algae suggests a reef environment [16] [20]. This facies matches facies (11) described by Flugel (2010) [20] and facies (5) by Wilson (1975) [16].

\subsection{Open Marine Facies Group (D)}

\section{D1) Bryozoan bioclast packstone}

Bryozoan bioclast packstone is characterized by grain-supported texture with richness of bryozoans fragments. The size of bryozoan debris ranges between 0.5 to $2.5 \mathrm{~mm}$. Red algae, bivalve and echinoderm fragments and peloids are subordinate constituents (Figure 9(c)). This facies matches facies (3) described by Flugel (2010) [20] and facies (4) by Wilson (1975) [16].

\section{D2) Red algal bioclast packestone/grainstone}

This facies chiefly is composed of skeletal grains especially red algae (lithophyllum and lithothamnion) fragments. Other skeletal grains are bivalve and echinoderm debris and briozoan (Figure 9(d)). Abundance of the crushed and carried grains shows this facies is the result of fragmentation of reef builder structures. This destroyed 
components of reef creates talus deposits in the fore reef depositional environment. This facies matches facies (4) described by Flugel (2010) [20] and facies (3) by Wilson (1975) [16].

\section{D3) claciturbidite}

This facies is characterized by wackestone to packstone facies with a combination of benthic and planktonic components (Figure 9(e)). The main constituents are crushed coral and red algae debris, benthic foraminifera such as miliolid and textularia, planktonic foraminifera, bivalve and echinoderm debris and peloid grains. This facies matches facies (4) described by Flugel (2010) [20] and facies (3) by Wilson (1975) [16].

\section{D4) Ostoracode wackestone}

This facies belongs to the deepest part of Qom Formation in the study area. This mud-supported facies mainly composed of ostracods, echinoderm and red algae fragments (Figure 9(f)). This facies matches facies (3) described by Flugel (2010) [20] and facies (2) by Wilson (1975) [16]. The mud-supported nature, a low abundance of benthic fauna and the absence of wave and current patterns show low energy calm open marine depositional setting for this facies.

\subsection{Depositional Environment}

Reconstruction and modeling of the Qom Formation, by looking at the Walter law (Walter's Law, 1985), based on field and laboratory exploration, and comparing them with of recent and ancient sedimentary environments [25] [26] indicated that Qom Formation in the study area is deposited to a carbonate shelf platform. In addition, the sudden changes in the basin slope, the presence of extensive barrier reef, the existence of calciturbidite and gravity sediments as well as the high proportion of grain-supported facies indicated that Qom Formation deposited on a carbonate platform system (Figure 10). In total, this model consists of two open and semi-enclosed sea separated from each other by a reefal barrier. Each of these environments has its own special facies.

Based on this, A1 facies is the shallowest and closest facies to the land that considering lack of allochems shells and bird-eye fabric, the middle and upper of the tidal environment is proposed for its formation. Then towards the lagoon is the facies A2 that by looking at the frequency of ostracods and large gastropodas in sparry calcite cement and lack of open marinebioclasts in this facies, the possibility of its formation has been identified as the lowest part of at the end of the tidal area. Then, toward the open sea, facies special to the environments with limited rotation of water, like facies B2 and B1 are observed. Type of allochems forming this facies like ingredients of milliloid and Gastropod family [22] [27] and micritic ground that has covered them (Flugel, 2010) [20] suggests restricted lagoon setting for these facies. Of other reasons, large size and low species diversity due to the salinity of the water in the lagoon can be stated. With increasing depth, facies C1 and C2 that depend on the energetic environment of the barrier formed. Sparry cement formed between the grains and lime mud is a

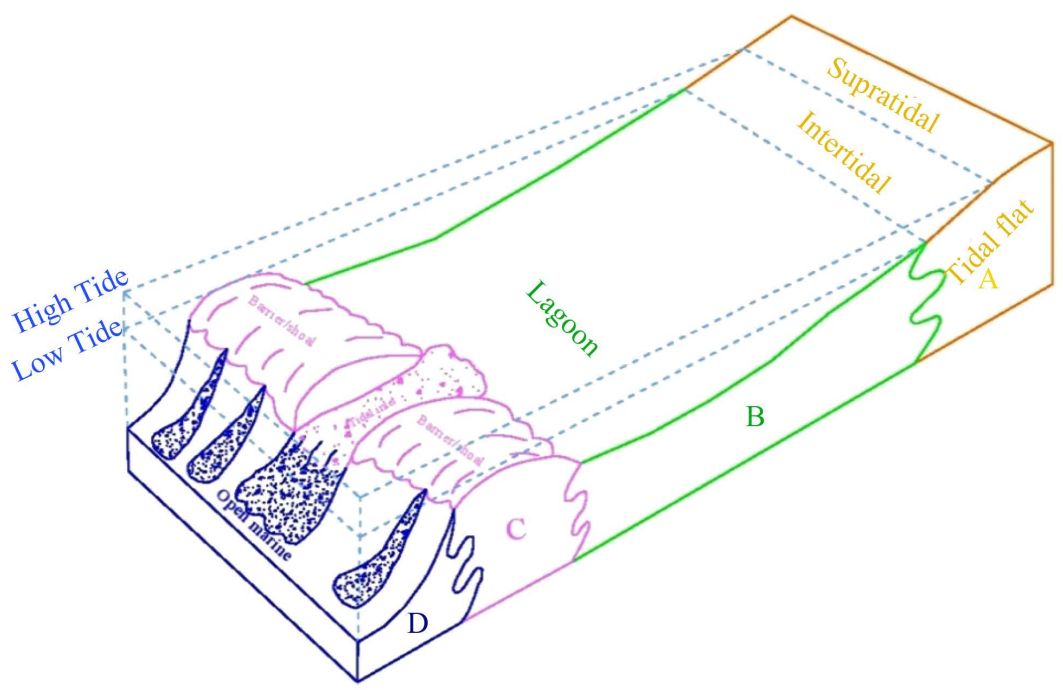

Figure 10. Schematic depositional model of the Qom Formation in the study area (no scale). 
sign of energetic environment [15]. Continental slope facies are formed of reef debris and debris flows where facies D3 is thought to be created in debris flow closer to the source. In the higher parts of the continental slope and channels on it, facies D3 appears and its thickness and coarseness of grains are of the signs of being near the origin about this facies. D4 facies is the deepest one related to open marine environment and the lower part of the slope is carbonate platform.

\section{Conclusions}

In this study, Qom Formation with thickness of $380 \mathrm{~m}$ in Saran section was investigated to identify microfacies, diagenetic features and depositional environment. The most important skeletal particles identified in this section various types of benthic foraminifera, red algae (lithophyllum and lithothamnion genus), echinoderms, Corals, Bryozoan, bivalves, gastropods, brachiopods and ostracods can be noted. Quartz, feldspar, rock fragment, glauconite and phosphate are the main non carbonate particles. Diagenetic processes affecting the Qom Formation in the studied section are cementation, dissolution, micritization, neomorphism, bioturbim, mechanical and chemical compaction, fracturing, dolomitization, and hematitization.

According to petrographic and facies analysis twelve microfacies are recognized in the Qom Formation in the studied area, that are arranged in four facies groups including tidal flat, lagoon, barrier and open marine. Field and laboratory examination and comparing with recent and ancient sedimentary environments indicated that Qom Formation in the Saran Semnan area is deposited to a carbonate shelf platform.

\section{Acknowledgements}

The authors acknowledge the Department of geology, Islamic Azad University, Science and Research branch, Tehran (Iran) and North Tehran Branch for funded this project. In addition, we thank Vice-President for Research in Science and Research branch, Tehran and North Tehran Branch.

\section{References}

[1] Aghanabati, SA.AS. (2004) Geology of Iran. Geological Survey of Iran, 586 p.

[2] Rahimzadeh, F. (1994) Geology of Iran, Oligocene, Miocene, Pliocene Geological Plan of the Book, Number 12, the Ministry of Mines and Metals, the Country’s Geological Survey, p. 311.

[3] Soleimani-Asl, S. and Aleali, M. (2016) Microfacies Patterns and Depositional Environments of the Sarvak Formation in the Abadan Plain, Southwest of Zagros. Open Journal of Geology, 6, 201-209. http://dx.doi.org/10.4236/ojg.2016.63018

[4] HajianBarzi, M., Aleali, M., Jahani, D. and FalahKheyrkhah, M. (2015) Microfacies, Sedimentary Environment, Sequence Stratigraphy and Strontium Dating of the Dashtak Formation in the Persian Gulf, Fars and Izeh Regions. Geosciences, 24, 185-198.

[5] Aleali, M., Rahimpour-Bonab, H., Moussavi-Harami, R. and Jahani, D. (2013) Environmental and Sequence Stratigraphic Implications of Anhydrite Textures: A Case from the Lower Triassic of the Central Persian Gulf. Journal of Asian Earth Sciences, 75, 110-125. http://dx.doi.org/10.1016/j.jseaes.2013.07.017

[6] Aleali, M., Rahimpour-Bonab, H., Moussavi-Harami, R., Jahani, D. and Asadi, A. (2013) Depositional Environment and Sequence Stratigraphy of the Kangan Formation in South Pars Field. Geosciences, 87, 65-74.

[7] Hassanvand, A. and Aleali, M. (2009) Study of Lithofacies, Microfacies and Depositional Environment of Asmari Formation in Parsi Oil Field. Journal of Sediment and Sedimentary Rock, 2, 82-73.

[8] Aleali, M., Feiznia, S. and Esmaeili, A. (2007) Sequence Stratigraphy of Sarvak Formation in Northwest of Behbahan (Maghar Valley). Applied Geology, 2, 80-86.

[9] Zare, S., Mosavi, M. and Aleali, M. (2007) Study of Microfacies and Sedimentary Environment of the Qom Formation in South of Saveh. Applied Geology, 3, 171-178.

[10] Chahida, M.R., Papp, A. and Steininger, F. (1997) Fossi Fahrung der oligo-Miocene Qom Formation inprofilenbei Abegarm—Zefreshbei Isfahan (Zentraliran), Beiträge zur paläontologie Österreichs, 79-93.

[11] Rahaghi, A. (1973) Etude do quelquegrands foraminifera de la formation de Oom (Iran Center). Revue de Micropaleontologie, 16, 23-38.

[12] Stocklin, J. and Setudehnia, A. (1971) Stratigraphic lexicon of Iran. Part 1: Central, North and East Iran. Geological Survey of Iran, Report No. 18, 376 p. 
[13] Daneshian, J. and Dana, I.R. (2007) Early Miocene Benthic Foraminifera and Biostratigraphy of the Qom Formation, DehNamak, Central Iran. Journal of Asian Earth Science, 29, 844-858.

[14] Schuster, E. and Wielandt, U. (1999) Oligocene and Early Miocene Coral Faunas from Iran: Paleo Biogeoraphy. International Journal of Earth Sciences, 88, 571-581.

[15] Dunham, R.J. (1962) Classification of Carbonate Rocks According to Depositional Texture. American Association of Petroleum Geologists Memorial 1, Tulsa, 108-121.

[16] Wilson, J.L. (1975) Carbonate Facies in Geological History. Springer, Berlin, 471. http://dx.doi.org/10.1007/978-1-4612-6383-8

[17] Reading, H.G. (1985) Sedimentary Environments and Facies. Blackwell Scientific Publications, Oxford, 615p.

[18] Tuker, M.E. (2001) Sedimentary Petrology. 3rd Edition. Blackwell, Oxford, 260.

[19] Pomar, L. (2001) Types of Carbonate Platforms: A Genetic Approach. Basin Research, 13, 313-334. http://dx.doi.org/10.1046/j.0950-091x.2001.00152.x

[20] Flugel, E. (2010) Microfacies of Carbonate Rocks, Analysis, Interpretation and Application. Springer, Berlin, 976.

[21] Folk, R.L. (1980) Petrology of Sedimentary Rocks. Hemphill Publishing, Austin, 184p.

[22] Bathurst, R.G.C. (1966) Boring Algae, Micrite Envelope and Lithification of Molluscan Biosparites. Geological Journal, 5, 15-32. http://dx.doi.org/10.1002/gj.3350050104

[23] Friedman, G.M. (1985) The Term Micrite or Micritic Cement Is a Contradiction-Discussion of Micritic Cement in Microborings Is Not Necessarily a Shallow-Water Indicator. Journal of Sedimentary Research, 55, 777. http://dx.doi.org/10.1306/212F87EC-2B24-11D7-8648000102C1865D

[24] Moore, C.H. (2001) Carbonate Reservoirs, Porosity Evolution and Diagenesis in a Sequence Stratigraphic Framework. Vol. 55, Development in Sedimentology, Elsevier, Amsterdam, 444 p.

[25] Noori, N. and Lasemi, Y. (1997) The Microfacies and Sedimentary Environments of Qom Formation in Semnan and Ardestan Area. Unpublished MSc Thesis, Tarbiyat Moallem University, Kharazmi, 86 p.

[26] Daneshian, J. and Chegini, A. (2007) Biostratigraphy of the Qom Formation in the Northeast and Southeast of Semnan. Geosciences, 16, 72-79.

[27] Purser. B.H (1973) The Persian Gulf, Holocene Carbonate Sedimentation and Diagenesis a Shallow Epicontinental Sea. Springer, Berlin. New York Palaeohistoria, 19, 18-85.

\section{Submit or recommend next manuscript to SCIRP and we will provide best service for you:}

Accepting pre-submission inquiries through Email, Facebook, Linkedin, Twitter, etc A wide selection of journals (inclusive of 9 subjects, more than 200 journals)

Providing a 24-hour high-quality service

User-friendly online submission system

Fair and swift peer-review system

Efficient typesetting and proofreading procedure

Display of the result of downloads and visits, as well as the number of cited articles

Maximum dissemination of your research work

Submit your manuscript at: http://papersubmission.scirp.org/ 